\title{
Description of Afipia birgiae sp. nov. and Afipia massiliensis sp. nov. and recognition of Afipia felis genospecies A
}

\footnotetext{
${ }^{1}$ Unité des Rickettsies, CNRS UPRESA 6020, Faculté de Médecine, Université de la Méditerrannée,

27 Boulevard Jean Moulin, 13385 Marseille Cedex 05, France

2 Unité des Entérobactéries, Unité INSERM 199, Institut Pasteur, 75724, Paris Cedex 15, France
}

\author{
Bernard La Scola, ${ }^{1}$ Marie-Noëlle Mallet, ${ }^{1}$ Patrick A. D. Grimont ${ }^{2}$ \\ and Didier Raoult ${ }^{1}$
}

\begin{abstract}
Author for correspondence: Didier Raoult. Tel: +33 04913855 17. Fax: +330491830390. e-mail: Raoult@Medecine.univ-mrs.fr
\end{abstract}

\begin{abstract}
On the basis of phenotypic characterization and DNA relatedness, two novel species are proposed, Afipia birgiae sp. nov. (type strain $34632^{\top}=$ CIP $_{106344^{\top}}=$ CCUG 43108') and Afipia massiliensis sp. nov. (type strain $34633^{\top}=$ CIP $^{\mathrm{T}} 107022^{\mathrm{T}}$ $=$ CCUG 45153'). A new genospecies is described, named Afipia felis genospecies A, closely related to Afipia felis. The complexity encountered in the taxonomy of the Bradyrhizobiaceae group within the $\alpha-2$ subgroup of the Proteobacteria is discussed and the description of these novel species highlights the need for new tools for phylogenetic analysis in the group. The novel species herein described are fastidious bacteria isolated from a hospital water supply in co-culture with amoebae. It is hypothesized that this group of bacteria are a potential cause of nosocomial infections.
\end{abstract}

\section{INTRODUCTION}

A previously undescribed Gram-negative bacillus was isolated from lymph nodes of patients with cat scratch disease (CSD) (English et al., 1988). This bacterium, which was shown to belong to the $\alpha$-Proteobacteria, was named Afipia felis (Brenner et al., 1991). Brenner et al. (1991) described the genus Afipia and two other species (Afipia clevelandensis and Afipia broomeae) and recognized three unnamed genospecies (1,2 and 3). Apart from the report by English et al. (1988), very little direct microbiological evidence linking A. felis and CSD has been presented and it is now clear that nearly all cases of CSD are due to a different bacterium, Bartonella henselae (Jerris \& Regnery, 1996). Birkness et al. (1992) demonstrated that A. felis has the capacity to grow intracellularly and have proposed a tissue culture protocol to isolate this species. The mechanism of intracellular survival of $A$. felis was shown to be due to a phagosome-lysosome inhibiting factor, uptake by macrophages being induced directly into a nonendocytic compartment (Brouqui \& Raoult, 1993; Lührmann et al., 2001). This bacterium has also been

Abbreviation: CSD, cat scratch disease. shown to have similar axenic growth requirements to Legionella spp. These findings led us to test whether $A$. felis, like legionellae, was able to parasitize free-living amoebae (La Scola \& Raoult, 1999). These co-culture studies did indeed demonstrate that $A$. felis has the ability to grow associated with amoebae, leading us to hypothesize that, in vivo, this species may exist in aquatic environments. By using an amoebal co-culture procedure, 68 strains of diverse $\alpha$-Proteobacteria were isolated from our hospital environmental supplies. By amplification and sequencing of the 16S rRNA genes of these isolates, several isolates were found that were closely related to Afipia species (La Scola et al., 2000). From the results of 16 rRNA gene sequencing of members of the Rhizobiaceae and DNA-DNA hybridization studies, two novel species, Afipia birgiae sp. nov. and Afipia massiliensis sp. nov., and a new genospecies, A. felis genospecies A, closely related to Afipia felis, are described.

\section{METHODS}

Strains. The strains used in this study are listed in Table 1. With the exception of $A$. felis strains, which were obtained from the American Type Culture Collection (ATCC, Manassas, VA, USA), all reference strains were obtained from the Collection de l'Institut Pasteur (CIP, Paris, France). All 
Table 1. Strains used in this study

\begin{tabular}{|c|c|}
\hline Strain & Reference(s) \\
\hline \multicolumn{2}{|l|}{ Afipia felis } \\
\hline B-91-007352 $(=$ ATCC 53690 $)$ & Brenner et al. (1991), English et al. (1988) \\
\hline B-91-007147 $(=$ ATCC 49714 $)$ & Brenner et al. (1991) \\
\hline B-90-007209 ( = ATCC 49715) & Brenner et al. (1991) \\
\hline B-90-007260 ( = ATCC 49716) & Brenner et al. (1991) \\
\hline \multicolumn{2}{|l|}{ Afipia clevelandensis } \\
\hline B-91-007353 ${ }^{\mathrm{T}}\left(=\right.$ ATCC $\left.49720^{\mathrm{T}}\right)$ & Brenner et al. (1991), Hall et al. (1991) \\
\hline \multicolumn{2}{|l|}{ Afipia broomeae } \\
\hline B-91-007286 $6^{\mathrm{T}}\left(=\mathrm{ATCC} 49717^{\mathrm{T}}\right)$ & Brenner et al. (1991) \\
\hline B-91-007288 ( = ATCC 49718) & Brenner et al. (1991) \\
\hline B-91-007289 ( = ATCC 49719) & Brenner et al. (1991) \\
\hline \multicolumn{2}{|l|}{ Afipia genospecies 1} \\
\hline B-91-007287 ( = ATCC 49721) & Brenner et al. (1991) \\
\hline \multicolumn{2}{|l|}{ Afipia genospecies 2} \\
\hline B-91-007290 ( = ATCC 49722) & Brenner et al. (1991) \\
\hline \multicolumn{2}{|l|}{ Afipia genospecies 3} \\
\hline B-91-007291 ( = ATCC 49723) & Brenner et al. (1991) \\
\hline \multicolumn{2}{|l|}{ Afipia genospecies 3-related strains } \\
\hline $34626(=\mathrm{CIP} 106343=\mathrm{CCUG} 43110)$ & La Scola et al. (2000) \\
\hline 34631 & La Scola et al. (2000) \\
\hline \multicolumn{2}{|l|}{ Afipia birgiae sp. nov. } \\
\hline $34632^{\mathrm{T}}\left(=\mathrm{CIP} 106344^{\mathrm{T}}=\mathrm{CCUG} 43108^{\mathrm{T}}\right)$ & La Scola et al. (2000) \\
\hline \multicolumn{2}{|l|}{ Afipia massiliensis sp. nov. } \\
\hline $34633^{\mathrm{T}}\left(=\mathrm{CIP} 107022^{\mathrm{T}}=\mathrm{CCUG} 45153^{\mathrm{T}}\right)$ & La Scola et al. (2000) \\
\hline \multicolumn{2}{|l|}{ Afipia felis genospecies A } \\
\hline $76713(=$ CIP $106335=$ CCUG 43109) & La Scola \& Raoult (1999), La Scola et al. (2000) \\
\hline
\end{tabular}

strains were routinely subcultured on BCYE agar plates (bioMérieux) at $30^{\circ} \mathrm{C}$.

Phenotypic tests. The morphological properties of the strains were studied following Gram and Gimenez staining (Gimenez, 1964). Oxidase activity was detected using a dimethyl- $p$-phenylenediamine oxalate disk (Pasteur Diagnostic). Catalase activity was detected by emulsifying a colony in $3 \%$ hydrogen peroxide and checking for the presence of microscopic bubbles. Other biochemical tests were performed by inoculation of API $20 \mathrm{NE}$ and API $50 \mathrm{CH}$ strips (bioMérieux) according to the manufacturer's instructions followed by incubation at $30^{\circ} \mathrm{C}$. These strips were respectively incubated for 7 and 15 days. The API 20NE strip tested for any reduction of nitrates, indole production, urease activity, glucose acidification, arginine dihydrolase activity, hydrolysis of gelatin and aesculin, $\beta$-galactosidase activity and assimilation of glucose, arabinose, mannose, mannitol, $N$-acetylglucosamine, maltose, gluconate, caprate, adipate, malate, citrate and phenylacetate. As interpretation of arginine dihydrolase and gelatinase activities on this strip was difficult, detection of these activities was later performed, according to the manufacturer's instructions, on ADH-ODC-LDC broth (Sanofi Diagnostics) and nutrient gelatin (Oxoid), respectively, which were then incubated at $30{ }^{\circ} \mathrm{C}$ for 7 days. $\mathrm{H}_{2} \mathrm{~S}$ production was tested using sodium thiosulfate substrate (bioMérieux). The API $50 \mathrm{CH}$ strip tested for any acidification of glycerol, erythritol, D-arabinose, L-arabinose, ribose, D-xylose, L-xylose, adonitol, methyl $\beta$-D-xyloside, galactose, glucose, fructose, mannose, sorbose, rhamnose, dulcitol, inositol, mannitol, sor- bitol, methyl $\alpha$-D-mannoside, methyl $\alpha$-D-glucoside, $N$ acetylglucosamine, amygdalin, arbutin, aesculin, salicin, cellobiose, maltose, lactose, melibiose, sucrose, trehalose, inulin, melezitose, raffinose, starch, glycogen, xylitol, gentiobiose, D-turanose, D-lyxose, D-tagatose, D-fucose, L-fucose, D-arabitol, L-arabitol, gluconate, 2-ketoglutarate and 5ketoglutarate. Growth and haemolysis were tested at $30^{\circ} \mathrm{C}$ on Columbia agar with $5 \%$ sheep blood (bioMérieux), Columbia agar (bioMérieux) enriched with $0.2 \%$ yeast extract (Merck) and 5\% sheep blood, MacConkey agar (bioMérieux) and nutrient broth (Difco) alone or with $6 \%$ $\mathrm{NaCl}$. Growth on BCYE agar was attempted at 25, 30, 35, 37 and $42{ }^{\circ} \mathrm{C}$. The presence of flagella was assessed by depositing bacteria cultured on BCYE agar plates on Formvar film and staining with a $0.33 \%$ solution of uranyl acetate before examination with a JEOL JEM 1200 EX electron microscope.

Antimicrobial susceptibility testing. The strains were grown for $72-96 \mathrm{~h}$ on BCYE agar prior to testing. Antibiotic susceptibility testing was performed using the microbroth dilution method in nutrient broth. For the testing of cotrimoxazole, $5 \%$ lysed horse blood was added. The final inoculum for all broth tests was $1 \times 10^{5}-5 \times 10^{5}$ c.f.u. $\mathrm{ml}^{-1}$. The plates were incubated at $30^{\circ} \mathrm{C}$ and read $72-96 \mathrm{~h}$ later. Escherichia coli ATCC 25922 and Enterococcus faecalis ATCC 29212 were used as controls.

SDS-PAGE analysis. The strains were harvested after 5-7 days of culture and suspended in deionized water for SDS-PAGE as described previously (Laemmli, 1970). Cell suspensions 
(titrated to $4 \mathrm{mg}$ protein $\mathrm{ml}^{-1}$ ) and sample buffer $0.0625 \mathrm{M}$ Tris $/ \mathrm{HCl}$, pH 8.0, 2\% SDS, 5\% 2-mercaptoethanol, $10 \%$ glycerol, $0.02 \%$ bromophenol blue) were mixed in equal volumes. The proteins were then separated by electrophoresis in a $12 \%$ resolving gel and a $5 \%$ stacking gel at a constant current $(8-10 \mathrm{~mA})$ at room temperature for $4 \mathrm{~h}$ in running buffer $(25 \mathrm{mM}$ Tris, $192 \mathrm{mM}$ glycine, $0 \cdot 1 \%$ SDS) in an electrophoretic cell (Mini Protein II; Bio-Rad).

Phylogenetic study. 16S rDNA amplification from $A$. felis genospecies A, A. birgiae sp. nov., A. massiliensis sp. nov. and Afipia genospecies 3-related strains has been described previously (La Scola et al., 2000). The phylogenetic relationships between Afipia and closely related bacteria were determined using PHYLIP software. Rickettsia prowazekii was taken as an outgroup. A distance matrix generated by DNADIST was determined under the assumptions of Kimura (1980). A dendrogram was inferred from this matrix using the neighbour-joining method (Saitou \& Nei, 1987). Bootstrap replicates were performed to estimate the reliability of nodes of the dendrogram obtained. Bootstrap values were obtained from 1000 trees generated randomly with SEQBOOT in the PHYLIP software package.

DNA-DNA relatedness. DNA was extracted and purified as described previously (Brenner et al., 1972). The procedures for labelling of DNA with tritium-labelled nucleotides and for hybridization experiments (S1 nuclease treatment, trichloroacetic acid procedure) have been detailed elsewhere (Grimont et al., 1980; Khammas et al., 1989).

G $+\mathbf{C}$ content analysis. DNA was extracted as described previously (Ausubel et al., 1995). Nucleoside residue analysis was performed by HPLC using a model L6200A system pump and a UV detector L4250 (Merck). A $5 \mu$ aliquot of sample was applied onto a Nucleosil 100-SC18 Lichrocart column $(4 \times 250 \mathrm{~mm})$ (Merck). Elution was carried out at room temperature using a mixture of $0.2 \mathrm{M} \mathrm{NH}_{4} \mathrm{H}_{2} \mathrm{PO}_{4}$ $(\mathrm{pH} 4 \cdot 5)$ and acetonitrile $(96: 4, \mathrm{v} / \mathrm{v})$. A flow rate of $1 \mathrm{ml}$ $\min ^{-1}$ was used and absorbance was monitored at $270 \mathrm{~nm}$. The calibration curve was obtained from a mixture of four standard nucleosides (Sigma) at a concentration of $0 \cdot 1 \mathrm{mg} \mathrm{ml} \mathrm{m}^{-1}$ each in distilled water. After chromatography, the relative concentration of each nucleotide was calculated on the basis of peak areas in HPLC dilution profiles and corrected by coefficients of relative molar absorption as described previously (Tamaoka \& Komagata, 1984).

Whole-cell fatty acid composition. Whole-cell fatty acids were analysed for $A$. felis genospecies A, A. birgiae sp. nov., A. massiliensis sp. nov. and Afipia genospecies 3-related strains by GC as described previously (Miller \& Berger, 1985) using 3- to 5-day-old cultures of the isolates grown on BCYE agar.

\section{RESULTS AND DISCUSSION}

The biochemical reactions that allow differentiation of the strains studied are given in Table 2. No strains gave visible colonies before $72 \mathrm{~h}$ at $30^{\circ} \mathrm{C}$ when grown on BCYE agar. All strains were Gram-negative, Gimenezpositive, oxidase-positive and weakly catalase-positive, had urease activity and grew on nutrient broth and Columbia agar with $5 \%$ sheep blood and $0 \cdot 2 \%$ yeast extract, but were not haemolytic. All strains assimilated gluconate and grew at 25 and $30^{\circ} \mathrm{C}$, but gave negative reactions in tests for arginine dihydrolase activity, aesculin and gelatin hydrolysis, $\beta$-galactosidase activity, $\mathrm{H}_{2} \mathrm{~S}$ production and acid production by fermentation or oxidation of substrates tested in API $50 \mathrm{CH}$. Strains failed to grow at $42{ }^{\circ} \mathrm{C}$ or on nutrient broth containing $6 \% \mathrm{NaCl}$. With the exception of $A$. birgiae sp. nov., all strains were motile by means of a single polar or subpolar flagellum. The strains differed in their abilities to grow on Columbia agar with $5 \%$ sheep blood, on MacConkey agar and at 35 and $37^{\circ} \mathrm{C}$, to reduce nitrate and to assimilate glucose, arabinose, mannose, mannitol, $N$-acetylglucosamine, gluconate, adipate, malate, citrate and phenylacetate. A. clevelandensis was the only strain that grew on MacConkey agar. Afipia genospecies 3-related strains, A. massiliensis sp. nov. and $A$. birgiae sp. nov. did not grow at 35 or $37^{\circ} \mathrm{C} ; A$. clevelandensis grew weakly at 35 , but not at $37^{\circ} \mathrm{C}$. A. felis, A. felis genospecies A, Afipia genospecies 3-related strains, $A$. birgiae and $A$. massiliensis were able to reduce nitrate. SDS-PAGE analysis revealed that each species yielded a specific protein profile (Fig. 1). However, different strains of the same species (A. felis, A. broomeae, Afipia genospecies 3related strains) yielded the same profile. A. felis genospecies A was distinguished from $A$. felis by the slightly lower molecular mass for a major protein band at about $50 \mathrm{kDa}$ and by the lack of a major protein of $17 \mathrm{kDa}$. A. birgiae and A. massiliensis could be differentiated by comparison of their low-molecularmass proteins. The whole-cell fatty acid compositions of the 17 strains are given in Table 3. These profiles showed that all strains shared relatively large amounts of hexadecanoic acid $\left(\mathrm{C}_{16: 0}\right)$, cis-octadec-9-enoic acid $\left(\mathrm{C}_{18: 1 \omega 7 c}\right)$ and octadecanoic acid $\left(\mathrm{C}_{18: 0}\right)$. With the exception of $A$. birgiae, all strains contained cishexadec-9-enoic acid $\left(\mathrm{C}_{16: 1 \omega 7 c}\right)$. Afipia genospecies 1 and Afipia genospecies 2 were the only species that contained cis-hexadec-7-enoic acid $\left(\mathrm{C}_{16: 1 \omega 5 c}\right)$. Afipia genospecies 3 and Afipia genospecies 3-related strains had no detectable cis-cyclo-10,11-methylene octadecanoic acid $\left(\mathrm{C}_{19: 0 \mathrm{cyclo \omega sc}}\right)$ and Afipia genospecies 3related strains and $A$. birgiae had no detectable 11methyloctadec-12-enoic acids $\left(\mathrm{C}_{\mathrm{Br} 19: 1}\right)$. A. birgiae and Afipia genospecies 3-related strains were the only strains that possessed 11-methyl cis-octadec-9-enoic acid $\left(\mathrm{C}_{18: 1 \omega 8 c}\right.$ 11-methyl). A. felis genospecies A differed from $A$. felis by the presence of a large amount of cis-octadec-9-enoic acid 11-methyl $\left(\mathrm{C}_{18: 1 \omega 7 c} 11\right.$ methyl). Antimicrobial susceptibility testing, summarized in Table 4 , showed that $A$. felis genospecies A may be differentiated phenotypically from A. felis by its high susceptibility to amoxicillin, cefalotin, ceftriaxon and cefepim. It is interesting to note that, if they are implicated in human infections, the only antibiotics that have reliably good efficacy on the Afipia group are rifampin and gentamicin, as reported for the strains studied previously (Brenner et al., 1991; Maurin et al., 1993).

The $\mathrm{G}+\mathrm{C}$ contents of Afipia species ranged from $59 \cdot 3$ to $69 \cdot 0 \mathrm{~mol} \%$. DNA-DNA hybridization demonstrated that $A$. felis genospecies A, A. massiliensis and 
Table 2. Biochemical reactions and $\mathrm{G}+\mathrm{C}$ contents of Afipia species

Species: 1, A. felis (4 strains); 2, Afipia felis genospecies A; 3, A. clevelandensis; 4, Afipia genospecies 1; 5, Afipia genospecies 2; 6, Afipia genospecies 3; 7, Afipia genospecies 3-related strains (2 strains); 8, A. broomeae (3 strains); 9, A. birgiae sp. nov.; 10, A. massiliensis sp. nov. + , Positive reaction; ${ }^{+}{ }^{w}$, weak; - , negative reaction. $\mathrm{G}+\mathrm{C}$ content data for strains other than $A$. felis genospecies A, A. birgiae, A. massiliensis and Afipia genospecies 3-related strains are from Brenner et al. (1991).

\begin{tabular}{|c|c|c|c|c|c|c|c|c|c|c|}
\hline Test & 1 & 2 & 3 & 4 & 5 & 6 & 7 & 8 & 9 & 10 \\
\hline Motility & + & + & + & + & + & + & + & + & - & + \\
\hline \multicolumn{11}{|l|}{ Growth on: } \\
\hline Columbia agar $/ 5 \%$ sheep blood & $+{ }^{\mathrm{w}}$ & $+{ }^{\mathrm{w}}$ & + & - & - & $+{ }^{w}$ & $+{ }^{w}$ & - & - & - \\
\hline MacConkey agar & - & - & $+{ }^{w}$ & - & - & - & - & - & - & - \\
\hline \multicolumn{11}{|l|}{ Growth on BCYE agar at: } \\
\hline $35^{\circ} \mathrm{C}$ & + & + & $+{ }^{w}$ & + & + & + & - & + & - & - \\
\hline $37^{\circ} \mathrm{C}$ & + & + & - & + & + & + & - & + & - & - \\
\hline Nitrate reduction & + & + & - & - & - & - & + & - & + & + \\
\hline \multicolumn{11}{|l|}{ Assimilation of: } \\
\hline Glucose & - & - & - & + & + & - & - & - & - & - \\
\hline Arabinose & - & - & - & + & + & - & - & - & - & - \\
\hline Mannose & - & - & - & + & + & - & - & - & - & - \\
\hline Mannitol & - & - & - & + & + & - & - & - & - & - \\
\hline$N$-Acetylglucosamine & - & - & - & + & + & - & - & - & - & - \\
\hline Gluconate & - & - & + & + & + & + & - & + & - & - \\
\hline Adipate & - & - & + & + & + & + & + & + & + & + \\
\hline Malate & + & + & + & + & - & + & + & + & - & - \\
\hline Citrate & - & - & - & + & - & - & - & - & - & - \\
\hline Phenylacetate & - & - & - & + & - & + & - & + & - & - \\
\hline $\mathrm{G}+\mathrm{C}$ content $(\mathrm{mol} \%)$ & $62 \cdot 5$ & $63 \cdot 1$ & $64 \cdot 0$ & $69 \cdot 0$ & $67 \cdot 0$ & $65 \cdot 5$ & $61 \cdot 9$ & $61 \cdot 5$ & $59 \cdot 3$ & $60 \cdot 2$ \\
\hline
\end{tabular}

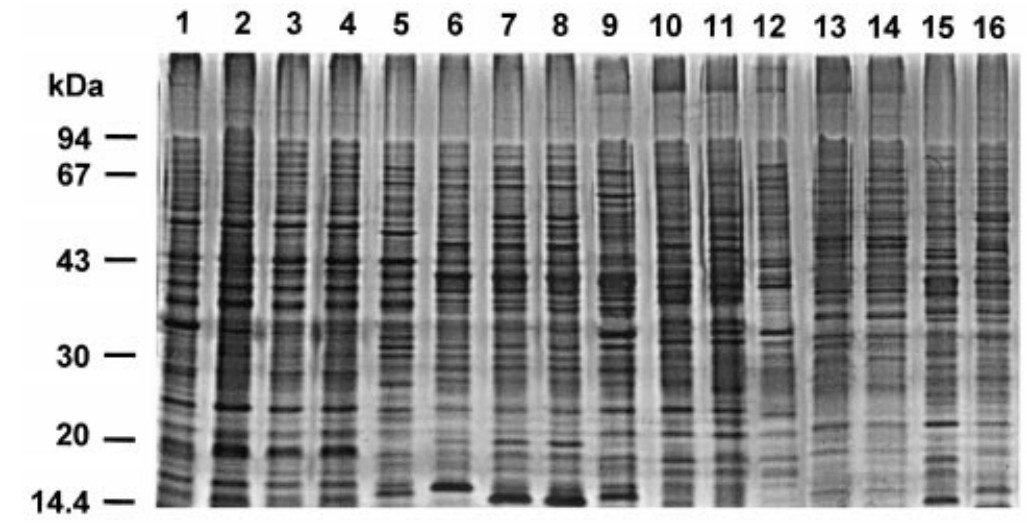

Fig. 1. Silver-stained SDS-PAGE gel of whole-cell protein preparation of Afipia species. Lanes: 1 , A. felis B-91-007352 ${ }^{\top} ; 2, A$. felis B-91-007147; 3, A. felis B-90-007209; 4, A. felis B-90-007260; 5, A. felis genospecies A; 6, A. broomeae B-91-007289; 7, A. broomeae B-91-007286 $; 8$, A. broomeae B91-007288; 9, A. clevelandensis; 10, Afipia genospecies $1 ; 11$, Afipia genospecies $2 ; 12$, Afipia genospecies $3 ; 13$, Afipia genospecies 3-related strain 34626; 14, Afipia genospecies 3-related strain $34631 ; 15, A$. birgiae; 16, A. massiliensis.

A. birgiae differed from previously described Afipia species (Table 5). Analysis of the 16S rRNA gene sequences of our hospital isolates and previously described Afipia species demonstrated that they belong to the Bradyrhizobium group, within the Rhizobiaceae, within the $\alpha$-Proteobacteria (Fig. 2). Nevertheless, the position of these bacteria within the Bradyrhizobium group is unclear. Within the Bradyrhizobium group, two major clusters can be distinguished: one that includes Bradyrhizobium elkanii (Kuykendall et al., 1992) and Afipia genospecies 1 and 2 (Brenner et al., 1991 ) and the other including Bradyrhizobium japonicum and Bradyrhizobium liaoningense (Jordan, 1982;
Xu et al., 1995), all other Afipia species and members of the genera Nitrobacter (Grundmann et al., 2000; Navarro et al., 1992; Orso et al., 1994; Sorokin et al., 1998), Agromonas (Ohta \& Hattori, 1983), Blastobacter (Hirsch \& Müller, 1985) and Rhodopseudomonas (Hougardy et al., 2000). Moreover, several 16S rRNA gene sequences of Afipia genospecies available in GenBank (Afipia genospecies 4-14), for which no description or strain is available, are distributed among very distant groups. It is clear that most of these 'Afipia' should not be considered as members of the genus Afipia or other genera of this group until strain descriptions are available. The inconsistencies in the 
Table 3. Fatty acid composition of Afipia strains

Values are percentages of total fatty acids. Strains: 1, A. felis (a, B-91-007352 ; b, B-91-007147; c, B-90-007209; d, B-90-007260); 2, A. felis genospecies A; 3, A. clevelandensis; 4, Afipia genospecies 1; 5, Afipia genospecies 2; 6, Afipia genospecies 3; 7, Afipia genospecies 3-related strains (a, 34626; b, 34631); 8, A. broomeae (a, B-91-007289; b, B-91-007286 ${ }^{\mathrm{T}}$; c, B-91-007288); 9, A.

birgiae; 10, A. massiliensis. Data for strains other than A. felis genospecies A, A. birgiae, A. massiliensis and Afipia genospecies 3related strains are from Brenner et al. (1991). tr, Less than $1 \% ;-$, not detected. $\mathrm{C}_{16: 0} 3-\mathrm{OH}$ and $\mathrm{C}_{18: 1 \omega 9 c}$ were not found in any of the strains shown.

\begin{tabular}{|c|c|c|c|c|c|c|c|c|c|c|c|c|c|c|c|c|}
\hline Fatty acid & 1a & 1b & $1 \mathrm{c}$ & 1d & 2 & 3 & 4 & 5 & 6 & $7 \mathbf{a}$ & $7 \mathrm{~b}$ & $8 \mathbf{a}$ & $\mathbf{8 b}$ & $8 c$ & 9 & 10 \\
\hline $\mathrm{C}_{15: 0}$ & - & - & - & - & - & - & 2 & $\operatorname{tr}$ & - & - & - & - & $\operatorname{tr}$ & - & 3 & - \\
\hline $\mathrm{C}_{16: 1 \omega 9 c}$ & - & - & - & - & - & - & - & - & - & - & - & - & - & - & 6 & - \\
\hline $\mathrm{C}_{16: 1 \omega 7 c}$ & 6 & 5 & 5 & 9 & 17 & 7 & 2 & 1 & 3 & 12 & 9 & 5 & 9 & 5 & - & 5 \\
\hline$C_{16: 105 c}$ & - & - & - & - & - & - & 4 & 3 & - & - & - & - & - & - & - & - \\
\hline $\mathrm{C}_{16: 0}$ & 4 & 3 & 3 & 4 & 3 & 3 & 6 & 6 & 9 & 23 & 18 & 4 & 5 & 4 & 3 & 5 \\
\hline $\mathrm{C}_{17: 1 \omega 9 c}$ & - & - & - & - & - & - & - & - & - & - & - & - & - & - & 12 & - \\
\hline $\mathrm{C}_{17: 108 c}$ & - & - & - & - & - & - & $\operatorname{tr}$ & - & 1 & - & - & $\operatorname{tr}$ & 1 & - & - & - \\
\hline $\mathrm{C}_{17: 106 c}$ & - & - & - & - & - & - & 6 & - & $\operatorname{tr}$ & - & - & - & - & - & - & - \\
\hline $\mathrm{C}_{17: 0 \text { cyclo }}$ & 7 & 9 & 13 & 11 & 13 & 16 & - & 3 & - & - & - & 22 & 15 & 22 & 25 & 22 \\
\hline $\mathrm{C}_{17: 0}$ & - & - & - & - & - & - & 3 & - & - & - & - & - & 3 & - & 18 & 1 \\
\hline $\mathrm{C}_{17: 0}$ iso $2-\mathrm{OH}$ & - & - & - & - & - & - & - & - & - & - & - & - & - & - & 11 & - \\
\hline $\mathrm{C}_{18: 1(c 11 / t 9 / t 6 ; 9 / t / 6 / c 11 ; t 6 / t 9 / c 11)}$ & - & - & - & - & - & - & - & - & - & - & - & - & - & - & 10 & - \\
\hline $\mathrm{C}_{18: 1 \omega 7 c}$ & 43 & 28 & 26 & 40 & 40 & 27 & 40 & 34 & 65 & 44 & 50 & 24 & 24 & 23 & - & 15 \\
\hline $\mathrm{C}_{18: 107 c}$ 11-methyl & - & - & - & - & 15 & - & - & - & - & 15 & 17 & - & - & - & - & 25 \\
\hline $\mathrm{C}_{18: 0}$ & 12 & 11 & 9 & 9 & 7 & 9 & 2 & 5 & 6 & 5 & 6 & 10 & 12 & 9 & 6 & 12 \\
\hline $\mathrm{C}_{18: 3 \omega 6 c}$ & - & - & - & - & - & - & - & - & - & $\operatorname{tr}$ & - & - & - & - & - & - \\
\hline $\mathrm{C}_{\mathrm{Br} 19: 1}$ & 14 & 24 & 23 & 13 & - & 30 & 24 & 30 & 15 & - & - & 25 & 23 & 25 & - & - \\
\hline $\mathrm{C}_{19: 0 \text { cyelow8c }}$ & 12 & 28 & 21 & 14 & 5 & 5 & 11 & 15 & - & - & - & 9 & 5 & 9 & & 14 \\
\hline $\mathrm{C}_{19: 0 \text { cycloc 11-12 }}$ & - & - & - & - & - & - & - & - & - & - & - & - & - & - & 3 & - \\
\hline $\mathrm{C}_{19: 0}$ & - & - & - & - & - & - & - & - & - & - & - & - & - & - & 3 & - \\
\hline $\mathrm{C}_{19: 0}$ iso & - & - & - & - & - & - & - & - & - & - & - & - & - & - & - & $\operatorname{tr}$ \\
\hline $\mathrm{C}_{20: 1 \omega 7 c}$ & - & - & - & - & - & - & - & - & - & - & - & - & - & - & - & 1 \\
\hline $\mathrm{C}_{20: 1 \omega 9 c}$ & - & - & - & - & - & 1 & - & - & - & - & - & 1 & 1 & 1 & - & - \\
\hline
\end{tabular}

classification of bacteria of the Bradyrhizobium group were highlighted soon after the official description of the genus Afipia (Willems \& Collins, 1992) and later by others working on the phylogeny of this group of bacteria (Anzai et al., 2000; Teske et al., 1994; Lafay \& Burdon, 1998; Wong et al., 1994; Willems et al., 2001; Hougardy et al., 2000). The key question raised by several authors is the validity of including these species in a single genus on the basis of $16 \mathrm{~S}$ rDNA sequences (as members of this group exhibit levels of sequence similarity of $97 \%$ or greater). It should be noted that genomic data are increasingly available for these species (up to $4016 \mathrm{~S}$ rDNA sequences for the Bradyrhizobium species) (Willems et al., 2001), but phenotypic data that could help in the polyphasic taxonomy of these bacteria are still lacking. As observed among Bradyrhizobium species and for the species described in this study or as described previously for Bacillus species (Ash et al., 1991; Fox et al., 1992), over-reliance on 16S rDNA sequence comparisons may be foolhardy and should therefore be associated with DNA-DNA hybridization data (Stackebrandt et al., 1994). In this study, A.felis and A.felis genospecies $\mathrm{A}$ represent two distinct genospecies on the basis of DNA-DNA hybridization and phenotypic data such as susceptibility to antibiotics, SDS-PAGE profile and whole-cell fatty acid composition (Wayne et al., 1987; Grimont et al., 1998), whereas they exhibit levels of $16 \mathrm{~S}$ rDNA sequence similarity of $99 \cdot 9 \%$. An approach comparing sequences from more divergent parts of the genome such as the rrs-rrl intergenic spacer has been described for Nitrobacter species (Grundmann et al., 2000) and Bradyrhizobium species (van Berkum et al., 2000) and seems to be more powerful for differentiation. It therefore appears that even slight divergence in 16S rDNA sequences of bacteria of this group should be considered as significant. Moreover, it seems difficult to group in the same genus, human pathogens such as Afipia, anaerobic photosynthetic bacteria such as Rhodobacter palustris, a budding chemoheterotroph such as Blastobacter denitrificans or nitrite-oxidizers such as members of the genus Nitrobacter. Improved classification of the Bradyrhizobium group could be obtained by delineating new genera that would better reflect the heterogeneity of this group. In the tree obtained in this study, several clusters may be delineated (Fig. 2), such as a cluster with Nitrobacter species, which is in accordance with the denomination of members of this genus and with a previous study using more divergent 
Table 4. Antimicrobial susceptibility profiles of Afipia species

Values are MIC $\left(\mathrm{mg}^{-1}\right)$. Strains: 1-10, see legend to Table 3; 11, Escherichia coli; 12, Enterococcus faecalis. AMC, Amoxicillin/clavulanic acid. For cotrimoxazole, the MIC is given for trimethoprim.

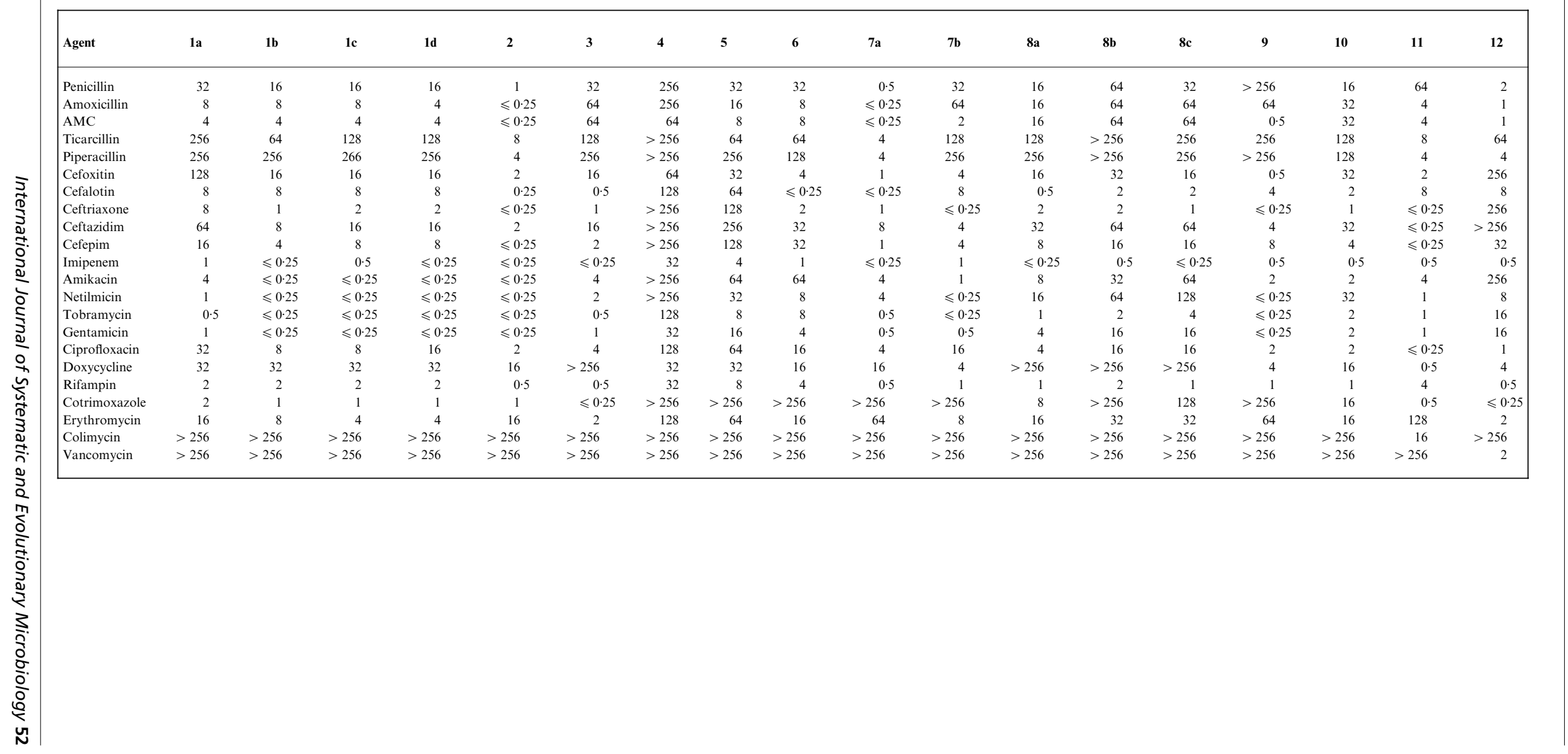


Table 5. DNA relatedness among Afipia species

\begin{tabular}{|c|c|c|c|c|}
\hline \multirow[t]{2}{*}{ Source of unlabelled DNA } & \multicolumn{4}{|c|}{ Relative reassociation (\%) with labelled DNA from strain: } \\
\hline & 34626 & $34632^{\mathrm{T}}$ & $34633^{\mathrm{T}}$ & 76713 \\
\hline A. felis B-91-007352 & 6 & 6 & 7 & 45 \\
\hline A. felis genospecies A strain 76713 & ND & ND & 6 & 100 \\
\hline A. clevelandensis $\mathrm{B}-91-007353^{\mathrm{T}}$ & 8 & 25 & 25 & 9 \\
\hline Afipia genospecies 1 strain B-91-007287 & 9 & 9 & 8 & 11 \\
\hline Afipia genospecies 2 strain B-91-007290 & 10 & 13 & 7 & 11 \\
\hline Afipia genospecies 3 strain B-91-007291 ${ }^{\mathrm{T}}$ & 10 & 6 & 7 & 9 \\
\hline Afipia genospecies 3-related strain 34626 & 100 & 7 & 1 & 4 \\
\hline Afipia genospecies 3-related strain 34631 & $97(0.9)^{*}$ & 5 & 1 & 3 \\
\hline A. broomeae B-91-007286 ${ }^{\mathrm{T}}$ & 8 & 29 & 29 & 13 \\
\hline A. birgiae sp. nov. $34632^{\mathrm{T}}$ & 6 & 100 & 40 & 8 \\
\hline A. massiliensis sp. nov. $34633^{\mathrm{T}}$ & 5 & 41 & 100 & 9 \\
\hline
\end{tabular}

${ }^{*} \Delta T_{\mathrm{m}}$ value (in ${ }^{\circ} \mathrm{C}$ ) given in parentheses.

ND, Not done.

genes (Grundmann et al., 2000), a cluster with A. felis, A. clevelandensis and $A$. felis genospecies $\mathrm{A}$ and $\mathrm{a}$ cluster with $A$. broomeae, A. birgiae and A.massiliensis. Conversely, the position of Afipia genospecies 3 and Afipia genospecies 3-related strains, which are different species but probably in the same genus, is impossible to assess. Afipia genospecies 1 and 2 should be placed in a separate genus with $B$. elkanii. It is thus proposed to exclude these four species from the genus Afipia. The development of new molecular tools, such as sequencing of the omp $A$ gene for Rickettsia species (Fournier et al., 1998), the rpoB gene for Enterobacteriaceae (Mollet et al., 1997) or the mip gene for Legionella species (Ratcliff et al., 1998), could help in the future to improve delineation of the different genera and species of this group.

The novel bacterial species described in this study were isolated from hospital water supplies using an amoebal co-culture procedure (La Scola et al., 2000). In this study, it has been demonstrated that these bacteria were phenotypically and genotypically closely related to bacteria of the genus Afipia. The reservoir natural niche of members of the genus Afipia, which are recognized as human pathogens (Brenner et al., 1991; Giladi et al., 1998; Hall et al., 1991; English et al., 1988), remains unknown. Most Afipia infections, including those caused by $A$. clevelandensis, $A$. broomeae and Afipia genospecies 1 and 2, have been associated with either the elderly or patients with other underlying medical problems. Afipia genospecies 3 was isolated from water (Brenner et al., 1991). An isolate of A. broomeae and Afipia genospecies 1 and 2 were isolated from pulmonary samples (Brenner et al., 1991). A. clevelandensis was isolated from a patient after months of hospitalization (Hall et al., 1991), supporting the conclusion that $A$. clevelandensis is capable of causing nosocomial infection. Furthermore, in a seroepidemiological study, several patients with elevated antibodies to this bacterium were diagnosed as having nosocomial infections including pneumonia (Drancourt et al., 1997). It is speculated that, as Afipialike bacteria have been isolated from hospital water supplies using amoebal co-culture, but have failed to grow on standard culture media, it is likely that, if they are causing hospital-acquired pulmonary infections, these are likely to be very difficult to diagnose.

\section{Emended description of the genus Afipia (Brenner et al. 1992)}

Afipia (A.fip'i.a. N.L. fem. n. Afipia derived from the acronym AFIP, for Armed Forces Institute of Pathology, where the type species was isolated).

Members of the genus are Gram-negative, but well stained by Gimenez staining, oxidase-positive, weakly catalase-positive rods in the $\alpha-2$ subgroup of the Proteobacteria. Most are motile by means of single polar or subpolar flagella. They grow on BCYE agar and nutrient broth, but not on nutrient broth containing $6 \% \mathrm{NaCl}$. All grow well at 25 and $30{ }^{\circ} \mathrm{C}$, but none grows at $42{ }^{\circ} \mathrm{C}$. Colonies are grey-white, glistening, convex and opaque. All are urease-positive. Negative for haemolysis, arginine dihydrolase activity, aesculin and gelatin hydrolysis, $\beta$-galactosidase activity, $\mathrm{H}_{2} \mathrm{~S}$ production and acid production by fermentation or oxidation of most carbon substrates, including glucose, fructose, mannose, sucrose, mannitol and maltose. The $\mathrm{G}+\mathrm{C}$ content is 59.3$64.0 \mathrm{~mol} \%$. The type species is Afipia felis.

\section{Description of Afipia birgiae sp. nov.}

Afipia birgiae (bir'gi.ae. N.L. fem. gen. n. birgiae of Birg, in honour of Marie-Laure Birg, a technician, for her many contributions to the isolation of strict intracellular bacteria, especially Tropheryma whipplei). 


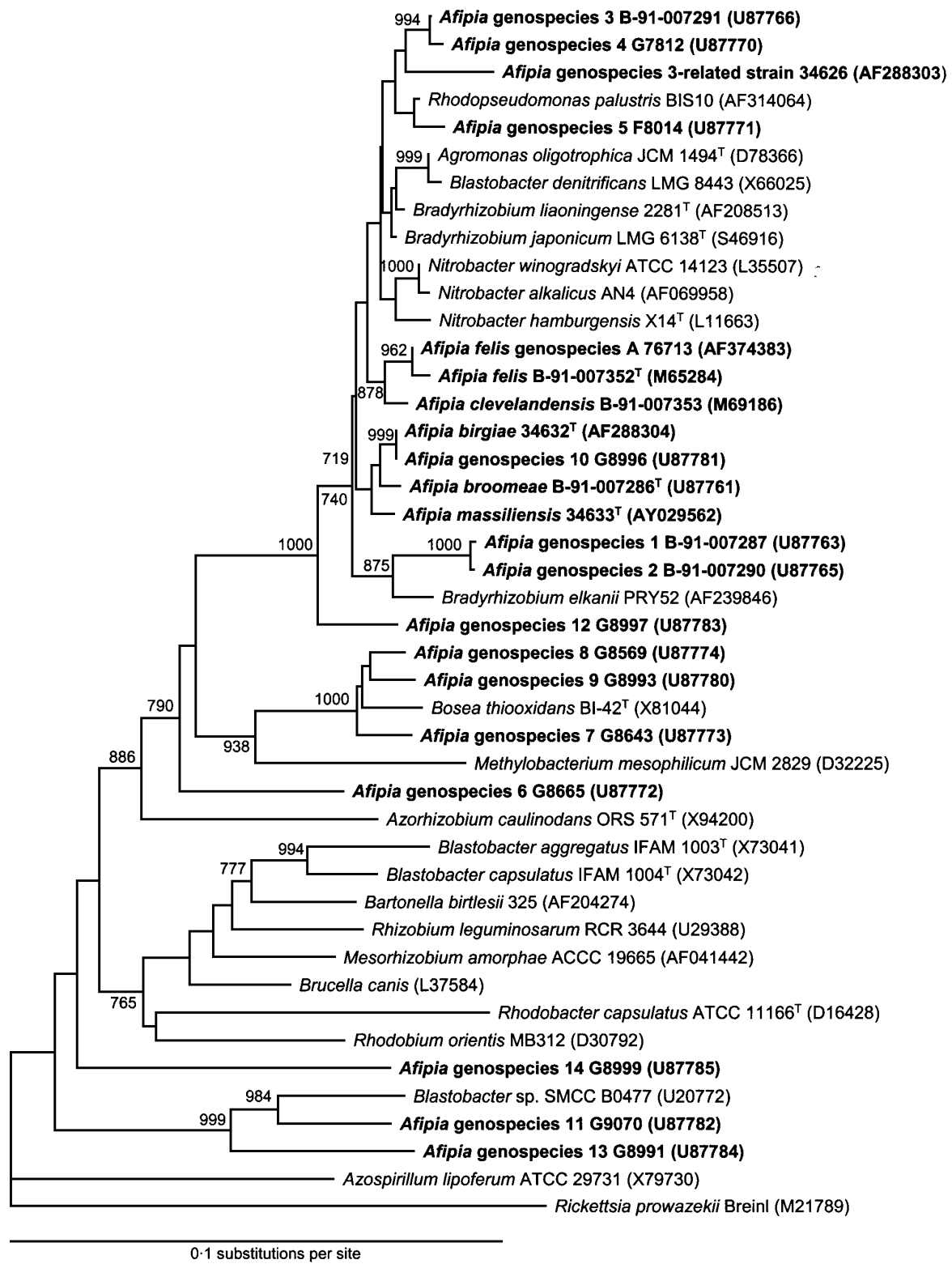

Fig. 2. Dendrogram representing phylogenetic relationships of Afipia species within the Bradyrhizobiaceae group and closely related bacteria among the $\alpha-2$ subgroup of the Proteobacteria. The tree was derived from a 1202 bp fragment of the 16S rRNA gene. Support for each branch, as determined from 1000 bootstrap samples, is indicated by the value at the node if $\geqslant 700 / 1000$.

Exhibits all of the characteristics of the genus, does not grow at $35{ }^{\circ} \mathrm{C}$ or on Columbia agar with $5 \%$ sheep blood and is not motile. Grows in co-culture with Acanthamoeba polyphaga in Page's amoebal saline. Reduces nitrate. Biochemical characteristics of use in differentiating this organism from other Afipia species are given in Table 2 . The whole-cell fatty acid profile is given in Table 3. The antimicrobial susceptibility profile is given in Table 4. The $\mathrm{G}+\mathrm{C}$ content is $59.3 \mathrm{~mol} \%$. Isolated from the water supply of the La Timone Hospital Centre (Marseilles, France). The type strain is strain $34632^{\mathrm{T}}\left(=\mathrm{CIP} 106344^{\mathrm{T}}=\mathrm{CCUG}\right.$ $43108^{\mathrm{T}}$ ).

\section{Description of Afipia massiliensis sp. nov.}

Afipia massiliensis (mas.si.li.en'sis. L. fem. adj. massiliensis referring to Massilia, Latin name of Marseille, where the organism was isolated).

Exhibits all of the characteristics of the genus, does not grow at $35{ }^{\circ} \mathrm{C}$ or on Columbia agar with $5 \%$ sheep blood and is motile. Grows in co-culture with Acanthamoeba polyphaga in Page's amoebal saline. Reduces nitrate. Biochemical characteristics of use in differentiating this organism from other Afipia species are given in Table 2. The whole-cell fatty acid profile is given in Table 3 . The antimicrobial susceptibility 
profile is given in Table 4. The $\mathrm{G}+\mathrm{C}$ content is $60 \cdot 2 \mathrm{~mol} \%$. Isolated from the water supply of the La Timone Hospital Centre (Marseilles, France). The type strain is strain $34633^{\mathrm{T}}\left(=\mathrm{CIP} 107022^{\mathrm{T}}=\mathrm{CCUG}\right.$ $\left.45153^{\mathrm{T}}\right)$.

\section{Description of Afipia felis genospecies A}

Exhibits all of the characteristics of the genus. Unique among members of the genus in its susceptibility to penicillins and cephalosporins. Reduces nitrate, grows at $37^{\circ} \mathrm{C}$ and in co-culture with Acanthamoeba polyphaga in Page's amoebal saline. Does not assimilate gluconate or adipate. Biochemical characteristics of use in differentiating this organism from other Afipia species and members of the genus Afipia are given in Table 2. The whole-cell fatty acid profile is given in Table 3. The antimicrobial susceptibility profile is given in Table 4 . The $\mathrm{G}+\mathrm{C}$ content is $63 \cdot 1 \mathrm{~mol} \%$. Isolated from the water supply of the La Timone Hospital Centre (Marseilles, France). The reference strain is strain 76713 ( $=$ CIP $106335=$ CCUG 43109).

\section{ACKNOWLEDGEMENTS}

The authors are indebted to Lina Barrassi and Elisabeth Ageron for technical help and R. J. Birtles for reviewing the manuscript.

\section{REFERENCES}

Anzai, Y., Kim, H., Park, J.-Y., Wakabayashi, H. \& Oyaizu, H. (2000). Phylogenetic affiliation of the pseudomonads based on $16 \mathrm{~S}$ rRNA sequence. Int J Syst Evol Microbiol 50, 1563-1589.

Ash, C., Farrow, J. A. E., Dorsch, M., Stackebrandt, E. \& Collins, M. D. (1991). Comparative analysis of Bacillus anthracis, Bacillus cereus, and related species on the basis of reverse transcriptase sequencing of 16S rRNA. Int J Syst Bacteriol 41, 343-346.

Ausubel, F. M., Brent, R., Kingston, R. E., Moore, D. D., Seidman, J. G., Smith, J. A. \& Struhl, K. (editors) (1995). Current Protocols in Molecular Biology. New York: Wiley.

Birkness, K. A., George, V. G., White, E. H., Stephens, D. S. \& Quinn, F. D. (1992). Intracellular growth of Afipia felis, a putative etiologic agent of cat scratch disease. Infect Immun 60, 2281-2287.

Brenner, D. J., Fanning, G. R., Rake, A. V. \& Johnson, K. E. (1972). Polynucleotide sequence divergence among strains of Escherichia coli and closely related organisms. J Bacteriol 109, 953-965.

Brenner, D. J., Hollis, D. G., Moss, C. W. \& 25 other authors (1991). Proposal of Afipia gen. nov., with Afipia felis sp. nov. (formerly the cat scratch disease bacillus), Afipia clevelandensis sp. nov. (formerly the Cleveland Clinic Foundation strain), Afipia broomeae sp. nov., and three unnamed genospecies. J Clin Microbiol 29, 2450-2460.

Brouqui, P. \& Raoult, D. (1993). Proteinase K-sensitive and filterable phagosome-lysosome fusion inhibiting factor in Afipia felis. Microb Pathog 15, 187-195.

Drancourt, M., Brouqui, P. \& Raoult, D. (1997). Afipia clevelandensis antibodies and cross-reactivity with Brucella spp. and Yersinia enterocolitica O:9. Clin Diagn Lab Immunol 4, 748-752.

English, C. K., Wear, D. J., Margileth, A. M., Lissner, C. R. \& Walsh, G. P. (1988). Cat-scratch disease. Isolation and culture of the bacterial agent. J Am Med Assoc 259, 1347-1352.

Fournier, P.-E., Roux, V. \& Raoult, D. (1998). Phylogenetic analysis of spotted fever group rickettsiae by study of the outer surface protein rOmpA. Int J Syst Bacteriol 48, 839-849.
Fox, G. E., Wisotzkey, J. D. \& Jurtshuk, P., Jr (1992). How close is close: $16 \mathrm{~S}$ rRNA sequence identity may not be sufficient to guarantee species identity. Int J Syst Bacteriol 42, 166-170.

Giladi, M., Avidor, B., Kletter, Y. \& 7 other authors (1998). Cat scratch disease: the rare role of Afipia felis. J Clin Microbiol 36, 2499-2502.

Gimenez, D. F. (1964). Staining rickettsiae in yolk-sac cultures. Stain Technol 39, 135-140.

Grimont, P. A. D. (1988). Use of DNA reassociation in bacterial classification. Can J Microbiol 34, 541-546.

Grimont, P. A. D., Popoff, M. Y., Grimont, F., Coynault, C. \& Lemelin, M. (1980). Reproducibility and correlation study of three deoxyribonucleic acid hybridization procedures. Curr Microbiol 4, 325-330.

Grundmann, G. L., Neyra, M. \& Normand, P. (2000). High-resolution phylogenetic analysis of $\mathrm{NO}_{2}^{-}$-oxidizing Nitrobacter species using the $r r s-r r l$ IGS sequence and $r r l$ genes. Int $J$ Syst Evol Microbiol 50, 1893-1898.

Hall, G. S., Pratt-Rippin, K. \& Washington, J. A. (1991). Isolation of agent associated with cat scratch disease bacillus from pretibial biopsy. Diagn Microbiol Infect Dis 14, 511-513.

Hirsch, P. \& Müller, M. (1985). Blastobacter aggregatus sp. nov., Blastobacter capsulatus sp. nov., and Blastobacter denitrificans sp. nov., new budding bacteria from freshwater habitats. Syst Appl Microbiol 6, 281-286.

Hougardy, A., Tindall, B. J. \& Klemme, J.-H. (2000). Rhodopseudomonas rhenobacensis sp. nov., a new nitrate-reducing purple nonsulfur bacterium. Int J Syst Evol Microbiol 50, 985-992.

Jerris, R. C. \& Regnery, R. L. (1996). Will the real agent of cat-scratch disease please stand up? Annu Rev Microbiol 50, 707-725.

Jordan, D. C. (1982). Transfer of Rhizobium japonicum Buchanan 1980 to Bradyrhizobium gen. nov., a genus of slow-growing root nodule bacteria from leguminous plants. Int J Syst Bacteriol 32, 136-139.

Khammas, K. M., Ageron, E., Grimont, P. A. D. \& Kaiser, P. (1989). Azospirillum irakense sp. nov., a nitrogen-fixing bacterium associated with rice roots and rhizosphere soil. Res Microbiol 140, 679-693.

Kimura, M. (1980). A simple method for estimating evolutionary rates of base substitutions through comparative studies of nucleotide sequences. J Mol Evol 16, 111-120.

Kuykendall, L. D., Saxena, B., Devine, T. E. \& Udell, S. E. (1992). Genetic diversity in Bradyrhizobium japonicum Jordan 1982 and a proposal for Bradyrhizobium elkanii sp. nov. Can J Microbiol 38, 501-505.

Laemmli, U. K. (1970). Cleavage of structural proteins during the assembly of the head of bacteriophage T4. Nature 227, 680-685.

Lafay, B. \& Burdon, J. J. (1998). Molecular diversity of rhizobia occurring on native shrubby legumes in southeastern Australia. Appl Environ Microbiol 64, 3989-3997.

La Scola, B. \& Raoult, D. (1999). Afipia felis in hospital water supply in association with free-living amoebae. Lancet 353, 1330.

La Scola, B., Barrassi, L. \& Raoult, D. (2000). Isolation of new fastidious $\alpha$-Proteobacteria and Afipia felis from hospital water supplies by direct plating and amoebal co-culture procedures. FEMS Microbiol Ecol 34, 129-137.

Lührmann, A., Streker, K., Schüttfort, A., Daniels, J. J. D. \& Haas, A. (2001). Afipia felis induces uptake by macrophage directly into a nonendocytic compartment. Proc Natl Acad Sci U S A 98, 7271-7276.

Maurin, M., Lepocher, H., Mallet, D. \& Raoult, D. (1993). Antibiotic susceptibilities of Afipia felis in axenic medium and in cells. Antimicrob Agents Chemother 37, 1410-1413.

Miller, L. \& Berger, T. (1985). Bacterial Identification by Gas Chromatography of Whole Cell Fatty Acids. Avondale, PA: HewlettPackard.

Mollet, C., Drancourt, M. \& Raoult, D. (1997). rpo $B$ sequence analysis as a novel basis for bacterial identification. Mol Microbiol 26, 1005-1011.

Navarro, E., Fernandez, M. P., Grimont, F., Clays-Josserand, A. \& 
Bardin, R. (1992). Genomic heterogeneity of the genus Nitrobacter. Int $J$ Syst Bacteriol 42, 554-560.

Ohta, H. \& Hattori, T. (1983). Agromonas oligotrophica gen. nov., sp. nov., a nitrogen-fixing oligotrophic bacterium. Antonie van Leeuwenhoek 49, 429-446.

Orso, S., Gouy, M., Navarro, E. \& Normand, P. (1994). Molecular phylogenetic analysis of Nitrobacter spp. Int J Syst Bacteriol 44, 83-86.

Ratcliff, R. M., Lanser, J. A., Manning, P. A. \& Heuzenroeder, M. W. (1998). Sequence-based classification scheme for the genus Legionella targeting the mip gene. J Clin Microbiol 36, 1560-1567.

Saitou, N. \& Nei, M. (1987). The neighbor-joining method: a new method for reconstructing phylogenetic trees. Mol Biol Evol 4, 406-425.

Sorokin, D. Y., Muyzer, G., Brinkhoff, T., Kuenen, J. G. \& Jetten, M. S. M. (1998). Isolation and characterization of a novel facultatively alkaliphilic Nitrobacter species N. alkalicus sp. nov. Arch Microbiol 170, 345-352.

Stackebrandt, E. \& Goebel, B. M. (1994). Taxonomic note: a place for DNA-DNA reassociation and $16 \mathrm{~S}$ rRNA sequence analysis in the present species definition in bacteriology. Int $J$ Syst Bacteriol 44, 846-849.

Tamaoka, J. \& Komagata, K. (1984). Determination of DNA base composition by reversed-phase high-performance liquid chromatography. FEMS Microbiol Lett 25, 125-128.

Teske, A., Alm, E., Regan, J. M., Toze, S., Rittman, B. E. \& Stahl,
D. A. (1994). Evolutionary relationships among ammonia- and nitriteoxidizing bacteria. J Bacteriol 176, 6623-6630.

van Berkum, P. \& Fuhrmann, J. J. (2000). Evolutionary relationships among the soybean bradyrhizobia reconstructed from $16 \mathrm{~S}$ rRNA gene and internally transcribed spacer region sequence divergence. Int $J$ Syst Evol Microbiol 50, 2165-2172.

Wayne, L. G., Brenner, D. J., Colwell, R. R. \& 9 other authors (1987). International Committee on Systematic Bacteriology. Report of the ad hoc committee on reconciliation of approaches to bacterial systematics. Int J Syst Bacteriol 37, 463-464.

Willems, A. \& Collins, M. D. (1992). Evidence of close genealogical relationship between Afipia (the causal organism of cat scratch disease), Bradyrhizobium japonicum and Blastobacter denitrificans. FEMS Microbiol Lett 75, 241-246.

Willems, A., Coopman, R. \& Gillis, M. (2001). Phylogenetic and DNA-DNA hybridization analyses of Bradyrhizobium species. Int $J$ Syst Evol Microbiol 51, 111-117.

Wong, F. Y. K., Stackebrandt, E., Ladha, J. K., Fleischman, D. E., Date, R. A. \& Fuerst, J. A. (1994). Phylogenetic analysis of Bradyrhizobium japonicum and photosynthetic stem-nodulating bacteria from Aeschynomene species grown in separated geographical regions. Appl Environ Microbiol 60, 940-946.

Xu, L. M., Ge, C., Cui, Z., Li, J. \& Fan, H. (1995). Bradyrhizobium liaoningense sp. nov., isolated from the root nodules of soybeans. Int $J$ Syst Bacteriol 45, 706-711. 